橈骨近位部の骨切術を行なつたが，外観的にも機能的 にも満足すべき結果であつた。手術法は Boyd の Approach に準じ Zaoussis の骨切術を参考とした.

\section{文献}

1) Blount, W. P.: Journal of Bone and Joint
Surgery, $22: 300,1940$.

2) Boyd, H. B.: Surgery, Gynecology and Obstetrics, $71: 86,1940$.

3) Campbell's Operative Orthopaedics: Fourth edition, pp. 129, London: Henry Kimpton.

4) Zaoussis, A. L.: Journal of Bone and Joint Surgery, 45-B : 523, 1963.

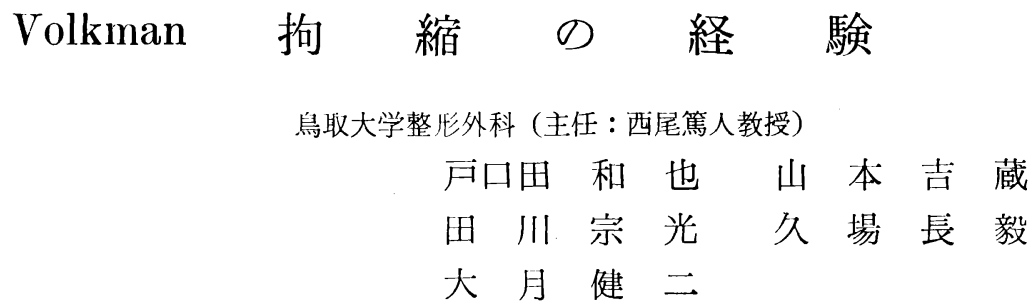

\title{
Clinical Study of Volkman's Contracture
}

By

K. Toguchida, K. Yamamoto, M. Tagawa, T. Kuba, and K. Ötuki

Department of Orthopedic Surgery, Tottori University, Medical School.

阻血性拘縮は 1881 年 Volkman がはじめて記載し て以来, 幾多の研究がなされているが, その成因につ いては未だ解明されていない点が多々ある. 従つてそ の治療法む種々で Dénuce（1920）のとなえた交感神 経説に基く交感神経切除術, 特に動脉周囲交感神経切 除術や, 腱延長, 骨短縮術, 手関節固定術等種々の 方法が行なわれており, 最近ではいわゆる tendon transfer (Parkes, 1951. Seddon, 1956) が行なわれ 良好な結果の報告がみられる。

われわれの教室における治験例はわずか 3 例ではあ るが, 2 例について遠隔成績が得られ, 又現在加療中 の 1 例を併せ, 若干の考察を加えて報告する.

症例 I : 合, 9 才. 昭和 30 年 9 月 8 日, 左上 腕骨顆上骨折をきたし, 外科医で整復固定をうけ于及 び指の運動並びに知覚障害をきたし, 受傷後 8 日目の 9 月16日に来院す.

所見：左上肢は上腕より 手指まで高度の腫脹があ り, 且つ水泡を形成し, 上腕骨中枢骨师は尺側前方に 突出し変版が著明で, 第 2 指〜 4 指の知覚脱失がみら
れた。レ線像でな去高度の転位が檍められ，即日観血 的骨接合術を行なつた。

経過 : 術後 2 日目より知覚脱失は稍々恢復し, 指の 運動むわずかにできるようになつた。

マッサージ，運動練翼を行なつたが次第に拘縮をき たし，レ線像で骨折部の屈側中央に過剩仮骨形成がみ られ，交感神経緊張元進（上田氏分類）屯認められた ので，受㑺後 72 日目（昭 30.11.18）左上腕動脉交感 神経切除術並びに正中神経剝離術を行なつた。

手術時の主な所見は, 骨折部周辺の軟部組織と痏痕 状に固く癒着している正中神経と，緊張はやや弱く， 且つ細くなつている上腕動脉であつた．何れも周囲と の瘾着を剝離し，瘢痕組織をできるだけ広範囲に除去 した. 仮骨も一部切除し, 術後 4 日目より橈骨動脉の 緊張屯次第に強くなつてきた。

結果 : 交感神経切除術後 8 年 6 力月（昭 39.5.31） の現在, 表に示すように極めて良好な成績がみられ， 回外制限の外は健側とほとんど変りなく, E. M.G. 及 び指尖脉波の所見にも著変はない（表1，図1). 


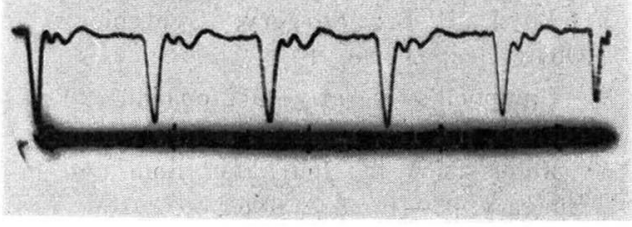

右 1 指

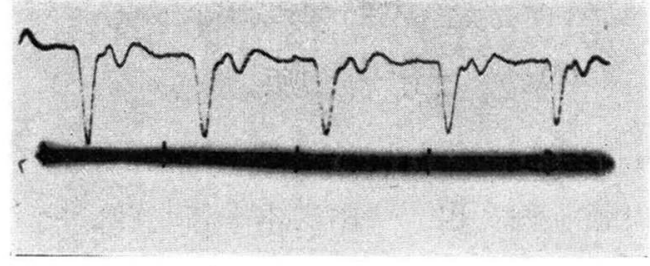

右 2 指

図 1

表 1 例: 術後 8 年 6 力月の現症

1)上腕周囲長右（趾） $26.5 \mathrm{~cm}$ 左（患） $25.0 \mathrm{~cm}$

2) 前腕周囲長右 (II) $29.0 \mathrm{~cm}$ 左 ("I) $29.0 \mathrm{~cm}$

3) 握 力右 ("I) $30.0 \mathrm{~kg}$ 左 ("I) $20.0 \mathrm{~kg}$

4）関節運動領域

\begin{tabular}{|c|c|c|c|c|}
\hline & & & 右（趾） & 左（患) \\
\hline 时 & $\begin{array}{l}\text { 屈 } \\
\text { 伸 }\end{array}$ & $\begin{array}{l}\text { 曲 } \\
\text { 展 }\end{array}$ & $\begin{array}{r}45^{\circ} \\
180^{\circ}\end{array}$ & $\begin{array}{r}45^{\circ} \\
170^{\circ}\end{array}$ \\
\hline 前 腕 & $\begin{array}{l}\text { 回 } \\
\text { 回 }\end{array}$ & $\begin{array}{l}\text { 岗 } \\
\text { 外 }\end{array}$ & $\begin{array}{l}90^{\circ} \\
30^{\circ}\end{array}$ & $\begin{array}{l}90^{\circ} \\
90^{\circ}\end{array}$ \\
\hline 手 & $\begin{array}{l}\text { 掌: } \\
\text { 背 } \\
\text { 橈 } \\
\text { 尺 }\end{array}$ & $\begin{array}{l}\text { 屈 } \\
\text { 屈 } \\
\text { 屈 } \\
\text { 屈 }\end{array}$ & $\begin{array}{r}90^{\circ} \\
120^{\circ} \\
30^{\circ} \\
60^{\circ}\end{array}$ & $\begin{array}{r}90^{\circ} \\
130^{\circ} \\
30^{\circ} \\
60^{\circ}\end{array}$ \\
\hline 指 & $\begin{array}{l}\text { 掌 } \\
\text { 背 }\end{array}$ & $\begin{array}{l}\text { 屈 } \\
\text { 屈 }\end{array}$ & 左右 同 & \\
\hline
\end{tabular}

5) 知覚障害 (一)

症例 II : 우, 6才. 昭和 35 年 9 月 18 日左上 腕骨顆上骨折を起し，接骨師のむとで治療をうけ，フ オルクマン拘縮を起し受㑺後 68 日目に来院す.

所見 : 図 2, a に示す所見を呈し, 第 5 指の D. I. P. 関節のみは 30 度の可動性を有していた. 全指の M.P. 関節より末梢の知覚脱失及び手根部より M. P. 関節に わたる知覚鈍麻があり, 発汗試験でむ知覚障嗐部位に 一致して発汗がみられない。

経過：受傷後 79 日目（昭 35.12.6）に変性した筋 肉の切除, 腱交換術及び神経剝離術を行なつた. 肘関 節の骨折部屈側より末梢へ S 字状の皮切を加え, 変性

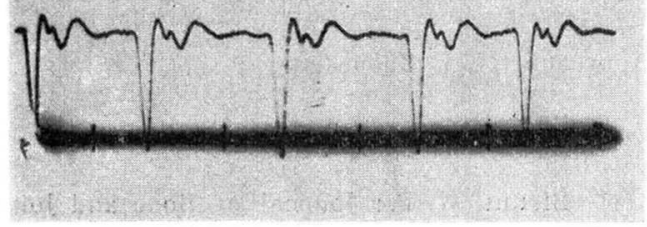

左 1 指

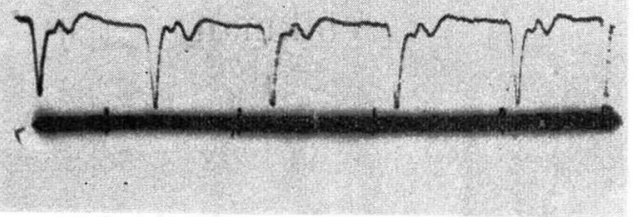

左 2 指

if $16 \Varangle(39.5 .31)$

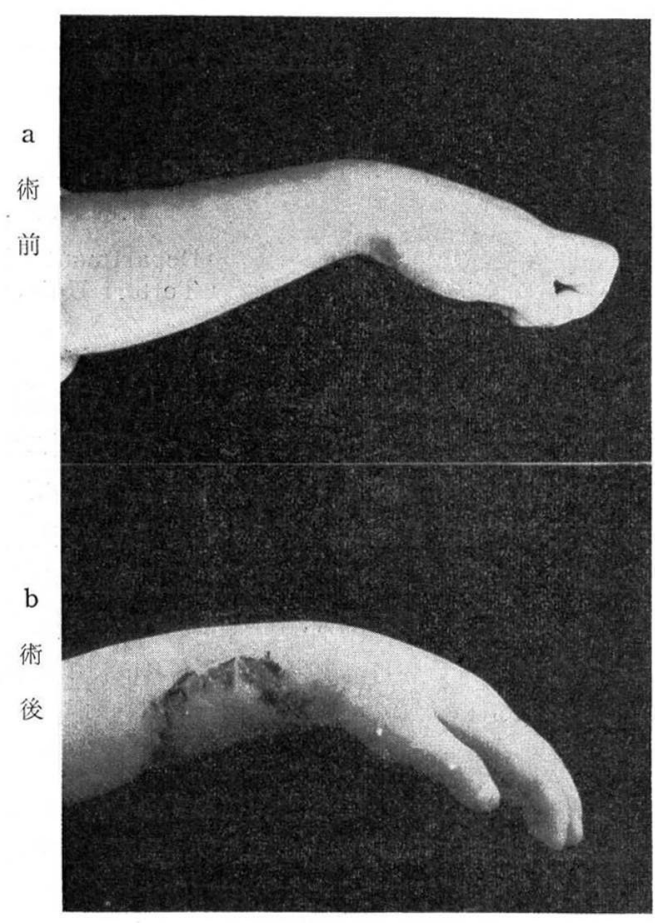

図 2

高度の浅及び深指屈筋を周囲之剝離, 切除し, 一部变 性のみられる長摭指屈筋も切除した. 正中神経は骨折 部で周井組織と夙着し稍々細くなつていたが，遠位部 は比較的正常に保たれていた. 長拇指屈筋は尺側手根 屈筋と, 又深指屈筋は長橈倒手根伸筋と縫合して術を 
終つた。

術後 2 日目より手指の伸展はわずかながら可能とな り，3 日目には略々中間位まで伸展可能となつた（図 $2, b)$.

結果 : 術後 3 年 6 力月（昭39.6）を経過した現症は 表に示す通りで, 術時高度の筋変性の生じていた前腕 屈筋では筋萎縮が可成りみられる. 拇指を除く 4 指の 可哑性は于手関節基本肢位では伸展，屆曲が可能である が，手関節背屈位では指の伸展が不能である. 知覚障 害は全くないが, 前腕屈筋の強い萎縮のため握力は減 退している(表 2 ).

表 $2 \square$ 例: 術後 3 年 6 力月の現症 ( I )

1)上腕周用長存（健） $18.0 \mathrm{~cm}$ 左（患） $16.5 \mathrm{~cm}$

2) 前腕周网長在 (II) $18.5 \mathrm{~cm}$ 左 (II) $13.0 \mathrm{~cm}$

3) 左側前腕屈側筋萎縮中等度 $(-3.5 \mathrm{~cm})$

4) 握 力右 (㯬) $20 \mathrm{~kg}$ 庄（患） $6.0 \mathrm{~kg}$

5) 関節運動領域

\begin{tabular}{|c|c|c|c|c|}
\hline & & & 存（健） & 左（患） \\
\hline 时 & 属 & $\begin{array}{l}\text { 曲 } \\
\text { 展 }\end{array}$ & $\begin{array}{r}40^{\circ} \\
180^{\circ}\end{array}$ & $\begin{array}{r}40^{\circ} \\
180^{\circ}\end{array}$ \\
\hline 前 腕 & $\begin{array}{l}|m| \\
|m|\end{array}$ & $\begin{array}{l}\text { 穴 } \\
\text { 外 }\end{array}$ & $\begin{array}{r}100^{\circ} \\
90^{\circ}\end{array}$ & $\begin{array}{l}50^{\circ} \\
80^{\circ}\end{array}$ \\
\hline 手 & $\begin{array}{l}\text { 背 } \\
\text { 掌 } \\
\text { 樈 } \\
\text { 尺 }\end{array}$ & $\begin{array}{l}\text { 屈 } \\
\text { 属 } \\
\text { 屈 } \\
\text { 屈 }\end{array}$ & $\begin{array}{r}115^{\circ} \\
95^{\circ} \\
30^{\circ} \\
60^{\circ}\end{array}$ & 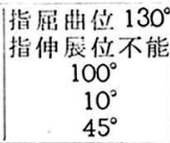 \\
\hline
\end{tabular}

指関節運動領域 MP PIP DIP MP PIP DIP

i) 手関節基本位：I $120^{\circ} 130^{\circ} 130^{\circ} 180^{\circ} 180^{\circ} 180^{\circ}$ II $130^{\circ} 130^{\circ} 130^{\circ} 180^{\circ} 180^{\circ} 170^{\circ}$ III $120^{\circ} 130^{\circ} 130^{\circ} 180^{\circ} 180^{\circ} 180^{\circ}$ IV $110^{\circ} 130^{\circ} 130^{\circ} 180^{\circ} 180^{\circ} 180^{\circ}$ $\mathrm{V} 110^{\circ} 130^{\circ} 130^{\circ} 180^{\circ} 180^{\circ} 180^{\circ}$

拇指: 外転正常, 内転 MP $130^{\circ}$, IP $135^{\circ}$ 他動的には可動性揵側と同

ii）手関節背屈位：屈曲

I - IV : MP, PIP 及び DIP $90^{\circ}$

6) 手掌筋萎縮 (一)

7) 知覚障害 (一)

症例 III : — 科㘣でギプス包带をうけ受倠後 9 日目に高度の阻血状 態をきたして来院す。

所見 : 不上腕より于指にわたる高度の腫脤と水泡形 成があり, 手背より手指の皮湓は暗赤色〜暗赤紫色を 呈し，ぬくむりは全く失つていた. 橈骨詯脉は全くふ れず，動脉撮影を行なつたととろ前腕遠位 $1 / 3$ 部で血 流は阻止されていた，前肳末端に骨折をみとめたが転
位は㹩度であつた。

経過 : 直ちに前腕䞨位 $1 / 3$ 部屈倒より手掌部にわた つて，筋膜及び靶带に縦切を加え減張を行なつたとこ ろ, 次第に出血が増加してくるのがみられた．橈骨動 脉の断裂はなかつた. 術後へパリン，チトマック及び ベリーナの投与む行なつたが，2 日目より指のぬくも りが生じ，指の色む vivid となり，㪇骨動脉の脉搏を 明らかにふれるようになつた，切開創の治㴔をまちマ ッサージ，運動練習を行なつたが拘縮は固く，副交感 神経緊張方進（上田氏分類）を認め，受㑺後 78 日目 に䣦脉周囲交感神経切除術及び正中神経䝆離術を行な つた.なお速続血管撮影を行なつたが 4 〜 秒で指骨 動脉まで血流は達するのがみられた（図 3 ).

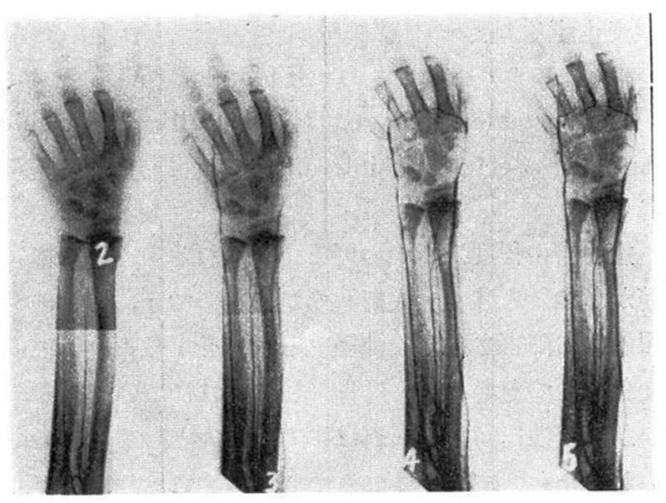

図 3: 例, 連続血管撮影

( 2 秒䦌隔，ウログラフィン20cc)

経過 : 手術時の主な所見は，高度に瘾着した正中神 経（約 $6 \mathrm{~cm}$ 長にわたつて絞扰）上，一部変性に陥つ た浅及び深指届筋であつた，神経は正常部位まで充分 に剝離し，橈側手根屈筋の固い瘢痕中に埋没されてい た橈骨動脉を周囲より剝離し，周辺の軟部組織を切除 した.

結果 : 術後日が浅く效果を論ずる段階ではないが, 術後翌日より手指運動練翼が柔かくできるようにな つた.

\section{考察}

フォルクマン拊縮に 対する 発生原因論は多々ある が, 1920 年. Dénuce が交感神経説を発表して以来多 くの支持者があり，特に 動脉周网交感神経切除術は 1920 年. Leriche により再認識され，しばしば行なわ れ，単なる Angiospasmus の場合は本法を行ない， 動脉閉鎤，惭裂の存する場会には閉銧動脉の部分切除 
と筋膜切開により好成績を得たと報告されている. 交感神経切除術の施行時期については多くの意見が あり, 初発徵候として 4 P, 即ち PAIN, PALER, PARALYSIS, PULSELESS が出現した場合には機 を失せずに，直ちに行なえとのべる早期手術有効論 (Griffiths, 1940) もあるが，野町等（1959）飞よる之 比較的陳旧例に対して屯効果が認められ，3 力月以内 の完治 3 例, 6 力月以内の有効 6 例が 報告されてい る. 回例は受伤後 72 日目に行なつたがすぐれた成 績が得られた。

局所貧血によつて起つた栓塞による筋の変性, 又は 壊死等の退行変性は, 前腕中央部にもつ之も高く, 且 つ中心部程変性が強く, 周辺部では副血行路のため比 較的怪度とされている.

又生ずる筋の障害は動脉病変の高さ, 貧血の 継続 時間により一定でなく, Seddon の述べるように 1) Reversible damage, 2) Partially reversible damage, 3) Irreversible damage にわけて考えら れる.

筋障害の程度は三つの例で認められるように深指屈 筋があつとも強く, 浅指屈筋がこれにつぎ, その他手 根届筋む障害される．神経です中心を走る正中神経の 変化がもつとも強く, 尺骨神経がこれについでいる. かかる変性に陥つた筋肉はすでに筋肉としての機能は 失われたもので, 生体にとつては異物であり, 流死, 変性に陥つた筋肉を残すことは術後の㦄着を增強し, 血行を障害する.

しかし Seddonは 16 例中に3 例が自然治瘾を示 し, うち 1 例は極めて高度で手術を断念したものであ
つたと報告しているが，皘極的に手術を行なうには少 くとも2〜3 力月の経過観察が必望と思われる.

なお阻血による前腕, 手根及び指骨の骨成長障害は 珰められなかつた。

\section{むすび}

1）動脉周囲交感神経切除術は 3 力月以内のものに は有効とされているが，72日目に行なつた】例では 優秀な成績がえられ，同時に充分な神経㓦離術の併用 が必要である。

2）壊死筋は全くの異物であり，切除が 望ましい が，手術時期を考慮すべきである.

3）末梢血管拡張剂ベリーナや，チトマックの使用 により手術はより効果的となり, 重症例を切断より救 うことができた。

（稿を終るに臨みご指導とご校閲を睗つた恩師四尼 教授に対し深甚の謝意を表する.)

\section{文献}

1) Griffiths, D. L.: J. Bone Joint. Surg, 30B, 280, 1948.

2) Griffiths, D. L.: Brit. J. Surg., 28, 239, 1940.

3）前人園三郎 -他: 整形外科。 $14,62,1963$.

4）野町昭三郎 - 他：整形外科. 10, 181, 1959.

5) Parkes, A.: J. Bone. Joint. Surg., 33-B, 359, 1951.

6) Seddon, H. G.: J. Bone Joint. Surg., 38B, 152, 1956.

7）津下煡哉・他：整形外科. 9, 161，1958.

8）津下健哉・他：整形外科. 14, 62, 1963. 